\title{
Morphological Make-up as the Predictor of English Word Accent
}

\section{Mohammad Ali Salmani-Nodoushan}

For years, phoneticians have tried to simplify pronunciation for EFL/ESL learners. Some have identified four degrees of primary, secondary, tertiary, and weak stress, and others only three degrees: primary, secondary, and weak. Still others have concentrated on two stress levels: accented versus unaccented, or stressed versus unstressed (Bowen, 1975; Stageberg, 1964; Chomsky \& Halle, 1968). None, however, has followed an orthography-based approach to English accent. Because orthography is the most static way of representing words in English, spelling- or orthography-based rules of accent/stress placement may come as a relief to ESL/EFL learners. In this article I present four spelling-based rules for stress placement to help EFL/ESL learners master pronunciation.

Depuis des années, les phonéticiens tentent de simplifier la prononciation pour les apprenants en ALE/ALS. Certains ont identifié quatre degrés d'accent tonique : primaire, secondaire, tertiaire et faible, alors que d'autres ne tiennent compte que de trois: primaire, secondaire et faible. Encore d'autres portent leur attention sur seulement deux niveaux d'accent tonique: accentué ou pas; ou avec accent tonique et sans accent tonique (Bowen, 1975; Stageberg, 1964; Chomsky \& Halle, 1968). Aucun phonéticien, par contre, n'a adopté une approche basée sur l'orthographe pour l'accent tonique en anglais. L'orthographe étant la façon la plus statique de représenter les mots en anglais, des règles sur l'accent tonique qui reposeraient sur l'orthographe pourraient s'avérer utiles pour les apprenants en ALS/ALE. Dans cet article, l'auteur présente quatre règles sur l'accent tonique qui reposent sur l'orthographe et qui visent à aider les apprenants en ALE/ALS à maîtriser la prononciation.

\section{Introduction}

Phoneticians have argued that English word stress is unpredictable. "There is no simple way of knowing which syllable or syllables in an English word must be stressed, but every time you learn another word you must be sure to learn how it is stressed" (O'Connor, 1967, p. 115). Gordon (1974) recommended a good dictionary as the simplest way to correct pronunciation as word accent is not that predictable. For years generative analysis of English phonology has afforded handy rules for stress placement (Birjandi \& Salmani-Nodoushan, 2005; Chomsky \& Halle, 1968; Dickerson, 1978, 1981, 1982, 
1985, 1986, 1989; Dickerson \& Finney, 1978). This article shows how morphological make-up can help to predict English word accent.

\section{Key Syllable (KS) and Left Syllable (LS)}

To begin with, ESL/EFL learners should be able to locate key and left syllables. In any English word there is a canonical syllable called the Key Syllable (KS) defined as the last vowel spelling pattern and all extra letters at the end of a word or before an ending (Yarmohammadi, 1995). Primary word stress is assigned either to the KS or to the syllable immediately to its left, the Left Syllable (LS).

KSs do not necessarily correspond to morphological and/or syllabification units; they all begin with a vowel $(\mathrm{V})$, which may be followed by another vowel, one consonant $(\mathrm{C})$ or more, or the letter $e$. For example,

$\begin{array}{rrrrr}\mathrm{VCE} & \mathrm{VV} & \mathrm{VCC} & \mathrm{V} & \mathrm{VC} \\ \text { decline } & \text { degree } & \text { enact } & \text { forgo } & \text { regret }\end{array}$

The two patterns VV and VCC may have extra following letters, none of which affects the basic pattern (e.g., feed, geese, bounce, peach).

Beginning with a vowel, the LS is the vowel spelling pattern and all extra letters immediately to the left of the KS. It includes all consonant letters up to the first vowel letter of the KS. For example:

$$
\mathrm{f} / \frac{\mathrm{org} / \mathrm{o}}{\mathrm{LS}} \quad \mathrm{d} / \frac{\mathrm{egr} / \mathrm{ee}}{\mathrm{LS}} \quad \mathrm{r} / \frac{\mathrm{egr} / \mathrm{et}}{\mathrm{LS}} \quad \mathrm{c} / \frac{\mathrm{ouns} / \mathrm{el} / \mathrm{ing}}{\mathrm{LS}} \mathrm{ref} / \frac{\mathrm{in} / \mathrm{ish} / \mathrm{es}}{\mathrm{LS}}
$$

ESL/EFL learners should also notice that word endings are either neutral (i.e., begin with a consonant) or accent-governing (i.e., begin with a vowel). Moreover, an $-e$ never precedes the neutral ending $-s$; where an $-e$ precedes a word-final $-s$, the - $e$ must always be included with the -s. Only accent-governing endings affect word accent. They fall into various categories and are discussed below.

The presence of a prefix may determine stress placement, and EFL/ESL learners should recognize major Anglo-Saxon (AS) and Latinate (L) prefixes. Moreover, some L prefixes undergo assimilation and take various alternate forms (see Appendixes A-C).

\section{Types of Accent Rules}

In this article I present four morphology-based accent rules: (a) Prefix Weak Accent Rule (PWAR), (b) V/VC Weak Accent Rule (V/VCWAR), (c) Key Strong Accent Rule (KSAR), and (d) Left Strong Accent Rule (LSAR).

\section{PWAR}

From the Key Syllable, accent the Left Syllable, but not a prefix; if you cannot accent the Left, then accent the Key. For PWAR to apply, EFL/ESL learners need to answer two questions:

1. Does the word belong to the domain of PWAR? 
2. Does the Left Syllable contain any part of a prefix?

The term domain is synonymous with part of speech (i.e., verbs, adverbs, adjectives and nouns). There are three possible answers to the second question: no, yes, or there is no LS. Each possibility entails a specific type of accent placement. Where there is no prefix in the LS, the accent falls on the LS; otherwise, it remains on the KS (see Table 1, Tables 1-5 are adapted from Yarmkammadi, 1995, with permission and modifications).

In consider and defines, for example, the accent is on the Key because the Left Syllables are prefixes, but in yellowing the accent is on the Left. In objectively the ending -ly is neutral and does not count, -ive is a weak ending and is within the domain of PWAR. But $o b$ - is a prefix and the accent falls on

Table 1

Word Domains for PWAR

\begin{tabular}{|c|c|c|c|}
\hline \multicolumn{2}{|c|}{ Category } & \multirow{2}{*}{$\begin{array}{l}\text { Part of Speech } \\
\text { V }\end{array}$} & \multirow{2}{*}{$\begin{array}{l}\text { Examples } \\
\text { to consider, to define, yellowing }\end{array}$} \\
\hline $1^{*}$ & verbs & & \\
\hline 2 & -atize & $\mathrm{V}$ & to anathematize, to democratize \\
\hline 3 & -atist & $\mathrm{N}$ & a systematist, a dogmatist \\
\hline 4 & -al & $\mathrm{N}$ & a cannibal, the survival \\
\hline 5 & -ure & $\mathrm{N}$ & the departure, the fürniture \\
\hline 6 & -ature & $\mathrm{N}$ & the literature, a signature \\
\hline 7 & -atism & $\mathrm{N}$ & the separatism, the pragmatism \\
\hline 8 & -est & Adj & flattest $\mathrm{N}$ \\
\hline 9 & -age & $\mathrm{N}, \mathrm{Adj}$ & the dosage, average $\mathrm{N}$ \\
\hline 10 & -ery & $\mathrm{N}, \mathrm{Adj}$ & the slavery, slippery $\mathrm{N}$ \\
\hline 11 & -or & $\mathrm{N}, \mathrm{Adj}$ & a bachelor, minor $\mathrm{N}$ \\
\hline 12 & -ed & Adj, Adv & unfinished $\mathrm{N}$, repeatedly \\
\hline 13 & $-y$ & Adj, Adv & tussocky $\mathrm{N}$, haughtily \\
\hline 14 & -er & $\mathrm{N}, \operatorname{Adj}, \operatorname{Adv}$ & the Jupiter, shallower $\mathrm{N}$, disorderly \\
\hline 15 & -ative & $\mathrm{N}, \mathrm{Adj}, \mathrm{Adv}$ & a preservative, generative $\mathrm{N}$, speculatively \\
\hline 16 & -able & $\mathrm{N}, \operatorname{Adj}, A d v$ & a syllable, unimaginable $\mathrm{N}$, remarkably \\
\hline 17 & -ary & N, Adj, Adv & a lapidary, so1 1 täry N, necessarily \\
\hline 18 & -ar & $\mathrm{N}, \mathrm{Adj}, \mathrm{Adv}$ & a calendar, pólar $\mathrm{N}$, circularly \\
\hline $19^{*}$ & -ible (Keys) & $\mathrm{N}, \operatorname{Adj}$, Adv & a convertible, invisible $\mathrm{N}$, audibly \\
\hline 20 & -ory & $\mathrm{N}, \mathrm{Adj}, \mathrm{Adv}$ & a directory, sensory $\mathrm{N}$, compulsorily \\
\hline 21 & -ive & $\mathrm{N}, \mathrm{Adj}, \mathrm{Adv}$ & a fugitive, pervasive $\mathrm{N}$, objectively \\
\hline 22 & -ing & $\mathrm{N}, \mathrm{Adj}, \mathrm{Adv}$ & a caviling, surprising $\mathrm{N}$, fittingly \\
\hline 23 & -atory & $\mathrm{N}, \mathrm{Adj}, \mathrm{Adv}$ & a reformatory, circulatory $\mathrm{N}$, obligatorily \\
\hline 24 & -ish & 2-syllable Adj & latish $\mathrm{N}$, sluggish $\mathrm{N}$ \\
\hline 25 & -ize & 2-syllable V & baptize, cognize \\
\hline 26 & -ist & 2-syllable N & a leftist, a flutist \\
\hline 27 & -ism & 2-syllable N & the racism, the baptism \\
\hline 28 & -en & all words & the pollen, uneven $\mathrm{N}$, to moisten, openly \\
\hline
\end{tabular}

${ }^{*}$ indicates categories that include exceptions 
the Key. Note that in the examples of each domain, the accented vowel is underlined and the Key Syllable is italicized. The letter N, which follows some of the examples, stands for noun head and indicates that examples are adjectives; similarly, verbs are indicated by to or -ing and nouns by $a$, an, or the.

Although categories 1 and 19 in Table 1 include exceptions, EFL/ESL learners should notice that verbs of three or more syllables that end in -ate, $-f y$, -ize, -ment, and -ute are governed by rules other than PWAR. Domain 19 includes all -ible words where -ible is the Key Syllable and may be uninflected or pluralized.

\section{V/VCWAR}

From a V or VC Key, accent Left; if you cannot accent Left (i.e., there is no LS, or the KS is not V or VC), then accent the Key (see Table 2).

$\mathrm{V} / \mathrm{VCWAR}$ applies principally to words with weak endings. To apply V/VCWAR, ESL/EFL learners must (a) identify word domains, and (b) recognize word endings. They should also decide where in the word to place the accent according to V/VCWAR (i.e., they must identify the KS and determine its spelling pattern). For example, in monumental the Key is VCC, in thesaurus VVC, and in flamboyancy VV. The accent will, therefore, remain on KS in these words. In analytically, the neutral -ly does not count and the KS

\section{Table 2}

Word Domains for V/VCWAR

\begin{tabular}{|c|c|c|c|}
\hline \multicolumn{2}{|c|}{ Category } & \multirow{2}{*}{$\begin{array}{l}\text { Part of Speech } \\
\text { all words }\end{array}$} & \multirow{2}{*}{$\begin{array}{l}\text { Examples } \\
\text { a mechanic, classic } \mathrm{N} \text {, to picnic }\end{array}$} \\
\hline $1^{*}$ & -ic Keys & & \\
\hline 2 & -ance & $\mathrm{N}$ & the tolerance, $\bar{a}$ allowance \\
\hline 3 & -ancy & $\mathrm{N}$ & the irrelevancy, the flamboyancy \\
\hline 4 & -ence & $\mathrm{N}$ & a residence, the convergence \\
\hline 5 & -ency & $\mathrm{N}$ & his constituency, an e-mergency \\
\hline 6 & -is & $\mathrm{N}$ & the genesis, a synopsis \\
\hline 7 & -oid & $\mathrm{N}$ & a trapezoid, an ellipsoid \\
\hline 8 & -um & $\mathrm{N}$ & a continuum, the referendum \\
\hline 9 & -us & $\mathrm{N}$ & an exodus, the thesaurus \\
\hline 10 & -ous & Adj, Adv & genererous $\mathrm{N}$, tremendously \\
\hline 11 & -al & $\mathrm{V}, \mathrm{Adj}, \mathrm{Adv}$ & to total, monumental $\mathrm{N}$, analytically \\
\hline 12 & -an & $\mathrm{N}, \mathrm{Adj}, \mathrm{Adv}$ & a toboggan, Américan $\mathrm{N}$, humanly \\
\hline 13 & -ant & $\mathrm{N}, \mathrm{Adj}, \mathrm{Adv}$ & an accountant, $\overline{a b}$ undant $\mathrm{N}$, militantly \\
\hline 14 & -ent & $\mathrm{N}, \mathrm{Adj}, \mathrm{Adv}$ & the president, different $\mathrm{N}$, consistently \\
\hline 15 & -on & $\mathrm{N}, \operatorname{Adj}, \mathrm{Adv}$ & the phlogiston, crimson $\mathrm{N}$, commonly \\
\hline
\end{tabular}

${ }^{*}$ indicates categories that include exceptions. 


\begin{tabular}{|c|c|}
\hline Strong Sequences & Examples \\
\hline eVSS & $\begin{array}{l}\text { area, corneal, ocean, linear, clypeate, rodeo, pigeon, petroleum, } \\
\text { caduceus hideous }\end{array}$ \\
\hline iVSS & 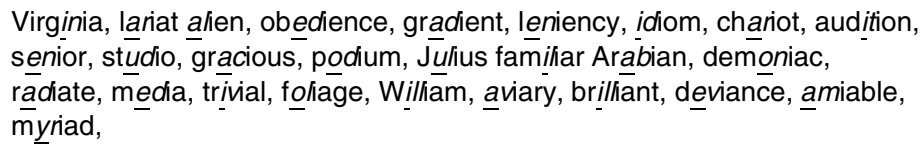 \\
\hline Exceptions & $\begin{array}{l}\text { words containing 'ies', 'ied', 'ier', and 'iest' strings and ie\# } \\
\text { words with VV Keys except for 'au', 'eu', and 'ou' }\end{array}$ \\
\hline
\end{tabular}

\#shows boundary; w\# means word-final and \#w means word initial (\#ie means word-final ie).

is VC, LS is accented. In total there is no LS and the accent falls on the KS. Moreover, in category 1 all words have a word-final -ic where $-i c$ is the KS.

KSAR

For a Strong Sequence (SS), accent the KS.

English SSs include $i \mathrm{~V}$ Strong Sequences (iVSS) (e.g., iar, ian, iac) and $e \mathrm{~V}$ Strong Sequences (eVSS) (e.g., eate, eo, eon). The iVSS category does not include the strings -ies, -ied, -ier, -iest, or word-final-ie. Unlike the term ending, the term sequence is neutral to position and is, therefore, preferred over the ending because patterns of accent occur not only word-finally but also wordmedially (e.g. stationary, behaviorism). In the word-medial position, $\mathrm{eV}$ sequences are unrestricted. Furthermore, where a word contains a strong sequence, word domain is irrelevant (see Table 3).

The syllable immediately to the left of the SS is the KS. The KS may be preceded by a Left Syllable (e.g., etr in petroleum) or may not (e.g., area). By excluding ies, ied, ier, and iest strings, and also ie\# (i.e., word-final ie), the learner can be sure that all other $i$ VSs are strong. Where final $y$ (i.e., $y \#)$ changes to $i$ before plural, superlative, comparative, or past morphemes (e.g., happiest), the resulting sequences are not real iVSSs. Moreover, for KSAR to operate, the KS in SSs should contain only one vowel; $a u$, eu, and ou are permitted (e.g., nauseous, Aleutian), but ue, ua, and uo cannot be the Key (e.g., situation, influential). Other exceptions include denial, appliance, classifiable, European, museum, and idea.

\section{LSAR}

For terminals and short nouns, accent the LS.

Notice that a word should it be submitted to LSAR only after is has failed to comply with any of the previous rules. 
The syllable third from the right in heavy (i.e., $3+$ syllabic) words is the antepenultimate syllable (see Table 4 ). In category 1 , the penultimate syllable is the KS, and the antepenultimate syllable is the LS; here the LS is accented. In $y$-final heavy nouns (category 2) too the LS is accented. Most bi-syllabic nouns in category 3 receive the accent on their penultimate syllables (i.e. their LSs). Words in category 4 too receive the accent on their antepenultimate syllables (i.e., the LS). The last spelling pattern within words in categories 1 , 2 , and 4 can point to the KS (i.e., they are neither sequences nor endings; rather, they are terminals). Notice that category 3 contains terminal-free bi-syllabic words consisting of an LS and a KS (i.e., light words, see Table 5). In each example, the KS is italicized and the LS underlined.

As the first refinement in words that end in terminals, if an SS occurs immediately to the left of the terminal, the KSAR applies, not the LSAR. For example,
ch / or / eogr / aph
un / ion / ist
$b / a c t / \underline{e r} /$ ios / tat
$\mathrm{ch}+\mathrm{KS}+\mathrm{SS}+\mathrm{T}$
$\overline{\mathrm{KS}}+\mathrm{SS}+\mathrm{T}$
$\mathrm{b}+\mathrm{LS}+\mathrm{KS}+\mathrm{SS}+\mathrm{T}$

Where LS = Left Syllable; KS = Key Syllable; SS = Strong Sequence; $\mathrm{T}=$ Terminal.

As the second refinement, heavy verbs must have no prefix immediately to the left of the terminal. This distinguishes between verbs like reinstate (PWAR) and reinstigate (LSAR):
re/inst/ig/ate
re/in/st / ate
$\mathrm{p}+\mathrm{LS}+\mathrm{KS}+\mathrm{T}$
$\mathrm{P}+\mathrm{P}+\phi+\overline{\mathrm{T}}$

Where $\mathrm{P}=$ prefix; $\phi=$ letter sequence that fails to count as a syllable.

As the third refinement, the LSAR operates on words that end in -ize, -ist, -ism, and -ish only if they include no weak ending or strong sequence (SS) immediately to the left of the terminal (e.g., westernize, determinism, devilish, psychologist).

Table 4

Word Categories of LSAR

\begin{tabular}{|c|c|c|}
\hline Category & Description & Example \\
\hline 1 & $\begin{array}{l}\text { heavy words* that do not end in a weak ending, a strong } \\
\text { sequence, or any highly recurrent syllable }\end{array}$ & $\begin{array}{l}\text { maverick, apocalypse, } \\
\text { stratagem, tenebrith }\end{array}$ \\
\hline 2 & heavy nouns that end in ' $y$ ' & industry, company \\
\hline 3 & bi-syllabic nouns that contain no special endings & $\begin{array}{l}\text { camel, city, product, } \\
\text { convoy }\end{array}$ \\
\hline 4 & $\begin{array}{l}\text { other heavy words not accented by PWAR, V/VCWAR, or } \\
\text { KSAR }\end{array}$ & $\begin{array}{l}\text { envelope, compensate, } \\
\text { democrat, energize }\end{array}$ \\
\hline
\end{tabular}

*Words with three or more syllables are often called heavy words. 
Moreover, in words that include internal weak endings, accent will be assigned according to the rule demanded by the weak ending in question (e.g., feverish, positivism, capitalize).

Light nouns with a V or VC in the KS often receive accent on the LS. Light nouns that contain VCC, VCe, or VV Key Syllables follow no solid rule for accent assignment; only a few KSs found within this category of light nouns retain accent consistently on themselves (e.g., -oon, -oo, -ese, -ade). For example,

baboon

bamboo Chinese

arcade

Overall, the key to the correct application of LSAR is that EFL/ESL learners must not mistake a weak ending or a word-final SS for a terminal. They should also be able to identify word domains by context clues, judge the number of spelled syllables in them, and locate the KS.

\section{Special Accent Cases}

In American English, two sets of morphologically complex words of Greek origin resist the application of LSAR:

1. words (ending in -archy,-mony, -doxy, -epsy, or -choly) with secondary accent on the KS before the $-y$ terminal that receive accent on the syllable immediately to the left of the LS (e.g., hierarchy, oligarchy, matrimony, testimony, epilepsy, melancholy, orthodoxy); and

Table 5

Word Domains of LSAR

\begin{tabular}{|c|c|c|c|}
\hline \multicolumn{2}{|c|}{ Category } & \multirow{2}{*}{$\begin{array}{l}\text { Part of Speech } \\
\text { heavy } \mathrm{N}\end{array}$} & \multirow{2}{*}{$\begin{array}{l}\text { Examples } \\
\text { the accuracy, the candidacy }\end{array}$} \\
\hline 1 & -acy (a unit) & & \\
\hline 2 & -ate & heavy words & to allocate, some chocolate, intimate $\mathrm{N}$ \\
\hline 3 & -ish & heavy Adj & de $\bar{v}$ ilish $\mathrm{N}$, yellowish $\overline{\mathrm{N}}$ \\
\hline 4 & -ism & heavy $\mathrm{N}$ & the determinism, the optimism \\
\hline 5 & -ist & heavy $\mathrm{N}$ & a monōpolist, a psychó 1 ogist \\
\hline 6 & -ize/-ise & heavy verb & to westernize, to merchandise \\
\hline 7 & -ute & heavy words & to constitute, a parachute, destitute $\mathrm{N}$ \\
\hline 8 & $-y$ & heavy N & the geography, the university \\
\hline 9 & $-y$ & heavy 'fy' words & to magnify, an amplifier, satisfying $\mathrm{N}$ \\
\hline 10 & $\begin{array}{l}\text { Less Frequent } \\
\text { Terminals }\end{array}$ & heavy $\mathrm{N}$ & $\begin{array}{l}\text { an acrobat, a boomerang, } \\
\text { a centipede, a phonograph, a telegram, a unicorn }\end{array}$ \\
\hline 11 & $\begin{array}{l}\text { Less Frequent } \\
\text { Terminals }\end{array}$ & heavy V & $\begin{array}{l}\text { to autograph, to flabbergast, } \\
\text { to pantomime, to ridicule, to sacrifice, to vivisect }\end{array}$ \\
\hline 12 & Less Frequent & heavy Adj & baritone $\mathrm{N}$, derelict $\mathrm{N}$, genuine $\mathrm{N}$, \\
\hline 13 & $\begin{array}{l}\text { Terminals } \\
\text { Light Noun }\end{array}$ & light $\mathrm{N}$ & $\begin{array}{l}\text { opposite } \mathrm{N} \text {, parallel } \mathrm{N} \text {, taciturn } \mathrm{N} \\
\text { a buzzard, a fäucet, a lantern, a record, a rebel, } \\
\text { a pýgmy }\end{array}$ \\
\hline
\end{tabular}


2. words with tri-syllabic prefixes (i.e., cinema-, encephalo-, entero-, cephalo-, hetero-, platino-, and sidero-) with accent on the first of the three syllables in the prefix (e.g. heterodox and sideroscope).

Often English words contain auto-accented sequences of a foreign origin (e.g., -ide, -alre, -ee, -eer, -esce, -esque, -eur, Vque, -ehe,-ier, -oo, and-oon), where the major accent falls on these word-final auto-accented sequences.

\section{Conclusion}

In this article I demonstrate that word stress in English is highly predictable on morphological grounds. I argue that EFL/ESL learners can predict the correct pronunciation of almost any English word provided they understand what is meant by Key Syllable (KS), Left Syllable (LS), Strong Sequence (SS), and terminal. Four morphology-based rules of stress placement are discussed and the few exceptions are explained.

\section{Acknowledgments}

I am grateful to the anonymous reviewers for the comments and suggestions they made for improving this article. My special thanks also go to Professor Lotfollah Yarmohammadi for his outstanding teaching of phonetics, which motivated me to write this article.

\section{The Author}

Mohammad Ali Salmani-Nodoushan is an assistant professor of applied linguistics in the English Department of the University of Zanjan, Iran. His research interests include language testing in general, testing English for Specific Purposes, and performance assessment in particular.

\section{References}

Birjandi, P., \& Salmani-Nodoushan, M.A. (2005). An introduction to phonetics. Tehran: Zabankadeh.

Bowen, J. (1975). Patterns of English pronunciation. Rowley, MA: Newbury House.

Chomsky, N., \& Halle, M. (1968). The sound pattern of English. New York: Harper and Row.

Dickerson, W. (1978). English orthography: A guide to word stress and vowel quality. IRAL, 16(2), 127-147.

Dickerson, W. (1981). A pedagogical interpretation of generative phonology: The main stress rules of English. TESL Studies, 4, 57-93.

Dickerson, W. (1982). A pedagogical interpretation of generative phonology: Vowels in the key and left syllables. TESL Studies, 5, 66-107.

Dickerson, W. (1985). A pedagogical interpretation of generative phonology: Vowels outside the key and left syllables. TESL Studies, 6, 38-63.

Dickerson, W. (1986). A pedagogical interpretation of generative phonology: Consonant choice. IDEAL, 1, 53-67.

Dickerson, W. (1989). Stress in the speech stream: The rhythm of spoken English. Urbana, IL: University of Illinois Press.

Dickerson, W., \& Finney, R. (1978). Spelling in TESOL: Stress cues to vowel quality. TESOL Quarterly, 12, 163-175.

Gordon, M. (1974). Speech improvement. Englewood Cliffs, NJ: Prentice Hall.

O'Connor, J. (1967). Better English pronunciation. Cambridge, UK: Cambridge University Press. Stageberg, N. (1964). An introductory English grammar. New York: Holt, Rinehart and Winston. 
Yarmohammadi, L. (1995). A contrastive phonological analysis of English and Persian: A course book in applied phonological studies. Shiraz: Shiraz University Press.

Appendix A: Basic Anglo-Saxon

\begin{tabular}{lll}
\hline Prefix & Meanings & Examples \\
\hline A- & at; in; on; in the act of & alike \\
BE- & to treat as; upon; against; thoroughly & besiege \\
DOWN- & down & downplay \\
FOR- & against & forswear \\
FORE- & before; in front of & misread \\
MIS- & wrongly & outspell \\
OUT & surpassing; outside & overspend \\
OVER- & to a greater/excessive degree; to become inverted & unwise \\
UN- & reverse action of; not & underline \\
UNDER- & below standard; deficient; beneath & uphold \\
UP- & up & withstand \\
WITH- & from & \\
\hline
\end{tabular}

\section{Appendix B: Most Frequent Latinate Prefixes}

\begin{tabular}{lll}
\hline Prefix & Meaning & Examples \\
\hline B- & from; away & abnormal \\
AD- & to; toward & adverb \\
CON- & with; together; joint & conveyance; coauthor \\
CONTRA- & in opposition to & contradict \\
COUNTER- & in opposition to & counterpart \\
DE- & down; from; the opposite of & determine; deactivate \\
DIS- & away from; the opposite of & discuss; dislike \\
EN- & in; make & enjoy \\
EX- & out; former & extort; ex-senator \\
EXTRA- & outside of & extravagant \\
EXTRO- & outside & extrovert \\
IN- & in; not & inspire; incomplete \\
INTER- & between & interleave \\
INTRA- & inside of; within & intravenous \\
INTRO- & inside of; within & introduce \\
MULTI- & many & multiethnic \\
NON- & not & nonmilitant \\
OB- & toward; in the way; the reverse of & objective \\
PER- & through (out); thoroughly & perplexing \\
POST- & after & postscript \\
PRE & before; beforehand & prepare; precondition \\
PRO- & forward; in favor of & provide; pro-Labor \\
RE- & back; again & reproach; redesign \\
RETRO- & back(ward) & retroactive \\
& &
\end{tabular}


SE-

SUB-

SUPER-

TRANS-

ULTRA- apart; without

under; secondary; smaller/less than

above; surpassing in kind

across; from one to another

beyond selective

subtract; subatomic

supertalented

transatlantic

ultramodern

\section{Appendix C: Alternate Forms of Most Frequent Latinate Prefixes}

\begin{tabular}{|c|c|c|}
\hline Prefix & Alternate Forms & Examples \\
\hline I. AD- & $\begin{array}{l}A C+C / Q \\
A F+F \\
A L+L \\
A N+N \\
A P+P \\
A R+R \\
A S+S \\
A T+T \\
A+S T \\
A D+\text { elsewhere* }\end{array}$ & $\begin{array}{l}\text { access; acquit } \\
\text { affect } \\
\text { allot } \\
\text { announce } \\
\text { appear } \\
\text { arrange } \\
\text { assure } \\
\text { attack } \\
\text { astute } \\
\text { admit; advise }\end{array}$ \\
\hline 2. CON- & $\begin{array}{l}\mathrm{COL}+\mathrm{L} \\
\mathrm{COR}+\mathrm{R} \\
\mathrm{COM}+\mathrm{B} / \mathrm{P} / \mathrm{M} \\
\mathrm{CO}+\text { vowel } \\
\mathrm{CON}+\text { elsewhere } \\
\mathrm{CO}+\text { free stem }\end{array}$ & $\begin{array}{l}\text { collect } \\
\text { correct } \\
\text { combine; compress; commit } \\
\text { coerce } \\
\text { conform; convince } \\
\text { co-partner }\end{array}$ \\
\hline 3. DIS- & $\begin{array}{l}\text { DIF + F } \\
\text { DI + voiced C** } \\
\text { DIS + elsewhere } \\
\text { DIS + free stem }\end{array}$ & $\begin{array}{l}\text { diffuse } \\
\text { dimension; divulge } \\
\text { dispel; distinct } \\
\text { disvalue }\end{array}$ \\
\hline 4. EN- & $\begin{array}{l}E M+B / P \\
E N+\text { elsewhere }\end{array}$ & $\begin{array}{l}\text { embark, employ } \\
\text { enchain, endear }\end{array}$ \\
\hline 5. EX- & $\begin{array}{l}E F+F \\
E+S C / S P / S T \\
E+\text { voiced } C \\
E X+\text { elsewhere } \\
E X+\text { free stem }\end{array}$ & $\begin{array}{l}\text { effect } \\
\text { escape; espouse; establish } \\
\text { erupt; emit } \\
\text { expel; extend } \\
\text { ex-wife }\end{array}$ \\
\hline 6. IN- & $\begin{array}{l}\mathrm{KS}+\mathrm{N} \\
\mathrm{IL}+\mathrm{L} \\
\mathrm{IM}+\mathrm{B} / \mathrm{P} / \mathrm{M} \\
\mathrm{IR}+\mathrm{R} \\
\mathrm{IN}+\text { elsewhere }\end{array}$ & $\begin{array}{l}\text { ignore } \\
\text { illegal } \\
\text { imbue; impair; immune } \\
\text { irreverent } \\
\text { intent; invite }\end{array}$ \\
\hline
\end{tabular}


7. OB-
$\mathrm{OC}+\mathrm{C}$
occupy

$\mathrm{OF}+\mathrm{F}$

offer

$\mathrm{OP}+\mathrm{P}$

oppress

$\mathrm{OB}+$ elsewhere

obscure; obtain

\begin{tabular}{lll}
\hline 8. SE & SE + C/D/L/V & secede; seduce; select; severe \\
\hline 9. SUB- & SUC + C & succeed \\
& SUF + F & suffice \\
& SUP + P & suppress \\
& SU + SP/ST/SC & suspect; sustain; susceptive \\
& SUB + elsewhere & submit; subtract \\
\hline 10. SUPER- & SUR- & surpass \\
& SUPER- & supervise \\
\hline
\end{tabular}

*Elsewhere means in any other context.

${ }^{*}$ Voiced $C$ refers to stems that begin with the letters $b, d, g, I, m, n, j, r$, and $v$, which represent voiced consonant sounds. 